\title{
Common Freshwater Fish Parasites Pictorial Guide: Motile Ciliates ${ }^{1}$
}

Deborah B. Pouder, Eric W. Curtis, and Roy P.E. Yanong ${ }^{2}$

\section{Introduction}

This publication is one in a series of pictorial guides that is designed to assist in the identification of common freshwater fish parasites. The publications included in this series are:

- Common Freshwater Fish Parasites Pictorial Guide: Sessile Ciliates

- Common Freshwater Fish Parasites Pictorial Guide: Motile Ciliates

- Common Freshwater Fish Parasites Pictorial Guide: Flagellates

- Common Freshwater Fish Parasites Pictorial Guide: Dinoflagellates, Coccidia, Microsporidians, \& Myxozoans

- Common Freshwater Fish Parasites Pictorial Guide: Monogeneans

- Common Freshwater Fish Parasites Pictorial Guide: Digenean Trematodes
- Common Freshwater Fish Parasites Pictorial Guide: Nematodes

- Common Freshwater Fish Parasites Pictorial Guide: Acanthocephalans, Cestodes, Leeches, \& Pentastomes

- Common Freshwater Fish Parasites Pictorial Guide: Crustaceans

The information provided in this guide is not intended to be a complete, detailed description of each parasite or parasite group and its characteristics but rather is intended to assist in the visual identification of some of the most common species or groups of parasites seen in freshwater fish. For further information on each parasite, refer to publications in the "Recommended Reading" and "Reference" sections below.

\section{Guide Information}

The following information is provided for each parasite on the guide.

1. This document is Fact Sheet FA-108, one of a series from the Tropical Aquaculture Laboratory, Department of Fisheries and Aquatic Sciences, Florida Cooperative Extension Service, Institute of Food and Agricultural Sciences, University of Florida. First published: July 2005. Please visit the EDIS Web Site at http://edis.ifas.ufl.edu.

2. Deborah B. Pouder, Coordinator of Research Programs and Services; Eric W. Curtis, former Biological Scientist, and Roy P.E. Yanong, Associate Professor, Tropical Aquaculture Laboratory, Ruskin, FL 33570, Department of Fisheries and Aquatic Sciences, Florida Cooperative Extension Service, Institute of Food and Agricultural Sciences, University of Florida.

The Institute of Food and Agricultural Sciences (IFAS) is an Equal Opportunity Institution authorized to provide research, educational information and other services only to individuals and institutions that function with non-discrimination with respect to race, creed, color, religion, age, disability, sex, sexual orientation, marital status, national origin, political opinions or affiliations. U.S. Department of Agriculture, Cooperative Extension Service, University of Florida, IFAS, Florida A. \& M. University Cooperative Extension Program, and Boards of County Commissioners Cooperating. Larry Arrington, Dean 
- Target Tissue: provides the location on/in the fish where the parasite is most commonly found.

- Characteristic: provides a brief description about the appearance of the parasite.

- Size: provides the size or size range of the parasite. $(1 \mu \mathrm{m}=0.001 \mathrm{~mm}=0.0001 \mathrm{~cm})(\mu \mathrm{m}$ $=$ micron or micrometer $; \mathrm{mm}=$ millimeter $; \mathrm{cm}=$ centimeter)

- Movement: provides the type of movement, if any, of the parasite.

- Note: provides a brief comment of interest about the parasite.

\section{Printing Tips}

For the best results as a pictorial guide, print this document in color on photo quality paper at a photo or "best" setting.

\section{Acknowledgements}

The authors thank Greg Vermeer for the photograph he contributed to this publication.

\section{Recommended Reading}

SRAC Publication No. 410 Calculating

Treatments for Ponds and Tanks. Southern Regional Aquaculture Center. http://srac.tamu.edu/410fs.pdf

SRAC Publication No. 475 Proliferative Gill Disease (Hamburger Gill Disease). Southern Regional Aquaculture Center. http://srac.tamu.edu/475fs.pdf

SRAC Publication No. 4701 Protozoan Parasites. Southern Regional Aquaculture Center. http://srac.tamu.edu/4701fs.pdf

UF/IFAS Circular 91 Nematode (Roundworm) Infections in Fish. http://edis.ifas.ufl.edu/FA091

UF/IFAS Circular 120 Fish Health Management Considerations in Recirculating Aquaculture Systems - Part 1: Introduction and General Principles. http://edis.ifas.ufl.edu/FA099
UF/IFAS Circular 121 Fish Health Management Considerations in Recirculating Aquaculture Systems - Part 2: Pathogens. http://edis.ifas.ufl.edu/FA100

UF/IFAS Circular 122 Fish Health Management Considerations in Recirculating Aquaculture Systems - Part 3: General Recommendations and Problem Solving Approaches. http://edis.ifas.ufl.edu/FA101

UF/IFAS Circular 716 Introduction to Freshwater Fish Parasites. http://edis.ifas.ufl.edu/FA041

UF/IFAS Circular 919 Stress--It's Role in Fish Disease. http://edis.ifas.ufl.edu/FA005

UF/IFAS Circular 920 Ichthyophthirius multifiliis (White Spot) Infections in Fish. http://edis.ifas.ufl.edu/FA006

UF/IFAS Circular 921 Introduction to Fish Health Management. http://edis.ifas.ufl.edu/FA004

UF/IFAS Fact Sheet FA-13 Use of Copper in Freshwater Aquaculture and Farm Ponds. http://edis.ifas.ufl.edu/FA008

UF/IFAS Fact Sheet FA-23 The Use of Potassium Permanganate in Fish Ponds. http://edis.ifas.ufl.edu/FA032

UF/IFAS Fact Sheet FA-28 Monogenean Parasites of Fish. http://edis.ifas.ufl.edu/FA033

UF/IFAS Fact Sheet FA-37 Use of Potassium Permanganate to Control External Infections of Ornamental Fish. http://edis.ifas.ufl.edu/FA027

UF/IFAS Fact Sheet FA-55 Submission of Fish for Diagnostic Evaluation. http://edis.ifas.ufl.edu/FA055

UF/IFAS Fact Sheet FA-90 Pentastomid Infections in Fish. http://edis.ifas.ufl.edu/FA090

UF/IFAS Fact Sheet FA-107 Common Freshwater Fish Parasites Pictorial Guide: Sessile Ciliates. http://edis.ifas.ufl.edu/FA107

UF/IFAS Fact Sheet FA-109 Common Freshwater Fish Parasites Pictorial Guide: Flagellates. http://edis.ifas.ufl.edu/FA109 
UF/IFAS Fact Sheet FA-110 Common

Freshwater Fish Parasites Pictorial Guide:

Dinoflagellates, Coccidia, Microsporidians, and

Myxozoans. http://edis.ifas.ufl.edu/FA110

UF/IFAS Fact Sheet FA-111 Common

Freshwater Fish Parasites Pictorial Guide:

Monogeneans. http://edis.ifas.ufl.edu/FA111

UF/IFAS Fact Sheet FA-112 Common

Freshwater Fish Parasites Pictorial Guide: Digenean

Trematodes. http://edis.ifas.ufl.edu/FA112

UF/IFAS Fact Sheet FA-113 Common

Freshwater Fish Parasites Pictorial Guide:

Nematodes. http://edis.ifas.ufl.edu/FA113

UF/IFAS Fact Sheet FA-114 Common

Freshwater Fish Parasites Pictorial Guide:

Acanthocephalans, Cestodes, Leeches, and

Pentastomes. http://edis.ifas.ufl.edu/FA114

UF/IFAS Fact Sheet FA-115 Common

Freshwater Fish Parasites Pictorial Guide:

Crustaceans. http://edis.ifas.ufl.edu/FA115

UF/IFAS Fact Sheet VM-67 Management of Hexamita in Ornamental Cichlids.

http://edis.ifas.ufl.edu/VM053

UF/IFAS Fact Sheet VM-77 Use of Formalin to Control Fish Parasites. http://edis.ifas.ufl.edu/VM061

UF/IFAS Fact Sheet VM-78 Bath Treatment for Sick Fish. http://edis.ifas.ufl.edu/VM037

UF/IFAS Fact Sheet VM-85 "Red Sore Disease" in Game Fish. http://edis.ifas.ufl.edu/VM059

UF/IFAS Fact Sheet VM-86 Use of Salt in Aquaculture. http://edis.ifas.ufl.edu/VM007

UF/IFAS Fact Sheet VM-87 Sanitation Practices for Aquaculture Facilities. http://edis.ifas.ufl.edu/AE081

UF/IFAS Fact Sheet VM-104 Cryptobia iubilans in Cichlids. http://edis.ifas.ufl.edu/VM077

\section{References}

Hoffman, G.L. 1999. Parasites of North American freshwater fishes. Cornell University Press, Ithaca, NY.

Longshaw, M and S.W. Feist. 2001. Parasitic diseases. Pages 167-183 in W.H. Wildgoose, editor. BSAVA manual of ornamental fish, second edition. British Small Animal Veterinary Association, Gloucester, England.

Noga, E.J. 1996. Fish disease: diagnosis and treatment. Mosby-Yearbook, Inc., St. Louis, MO.

Stoskopf, M.K. 1993. Fish medicine. W.B. Saunders Company, Philadelphia, PA.

Woo, P.T.K., editor. 1995. Fish diseases and disorders, volume 1: protozoan and metazoan infections. CAB International, Wallingford, United Kingdom. 

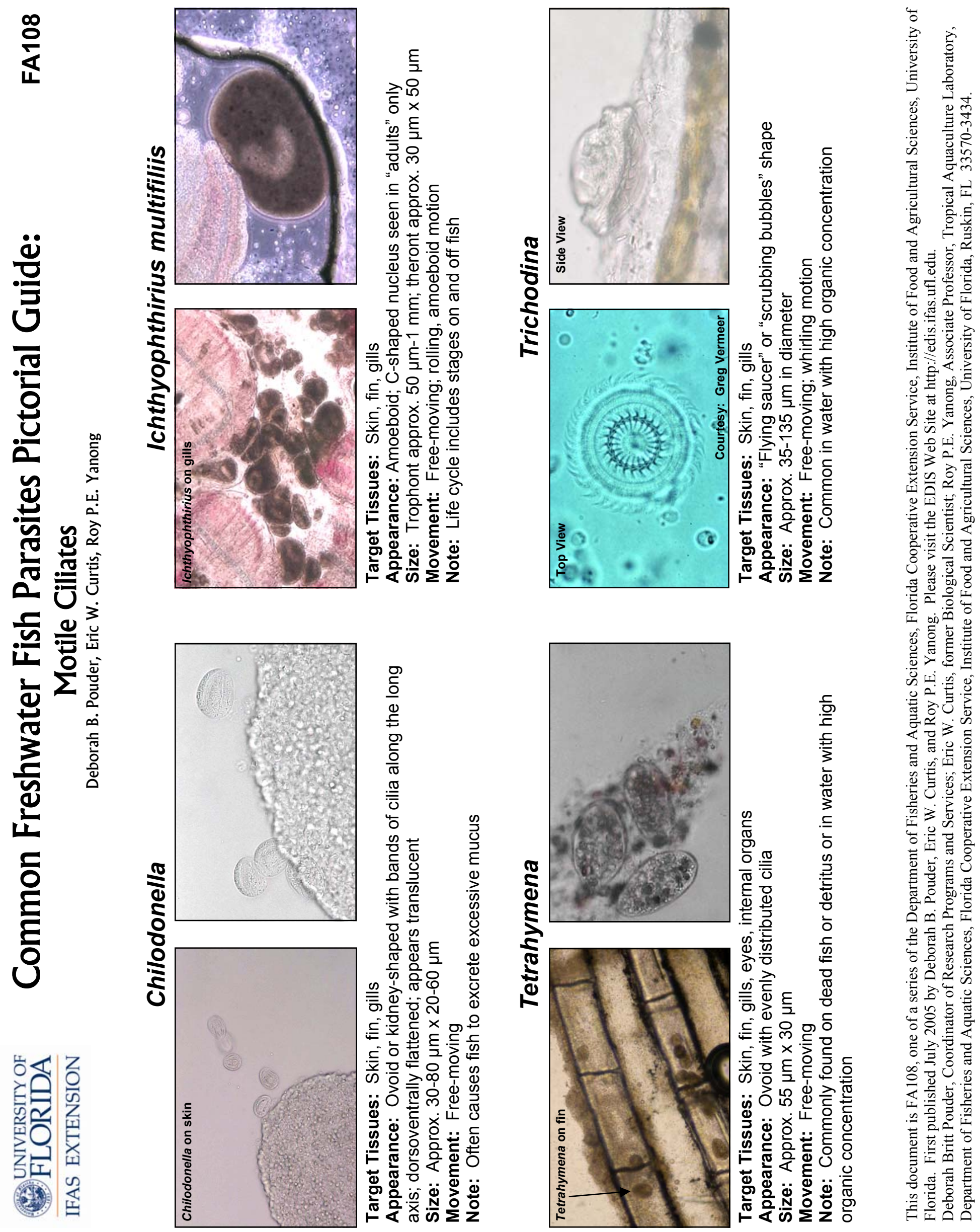